\title{
Remittances and Economic Growth Tie in Selected South Asian Countries: A Panel Data Analysis
}

\author{
Md. Nezum Uddin ${ }^{1}$, Mohammed Jashim Uddin ${ }^{1}$, Joynal Uddin $^{1}$ \& Monir Ahmmed ${ }^{1}$ \\ ${ }^{1}$ Department of Economics \& Banking, International Islamic University Chittagong (IIUC), Kumira, Bangladesh \\ Correspondence: Md. Nezum Uddin, Assistant Professor, Department of Economics \& Banking, International \\ Islamic University Chittagong (IIUC), Kumira, Chittagong-4318, Bangladesh. Tel: 88-018-1873-5047.
}

Received: September 23, 2019

doi:10.5430/ijfr.v11n1p197
Accepted: October 30, $2019 \quad$ Online Published: November 3, 2019

URL: https://doi.org/10.5430/ijfr.v11n1p197

\begin{abstract}
Remittances are regarded one of the foremost financial resources globally. Over the past century, in the developing economy, there is a heated debate on the sources of economic growth. The current paper attempts to analyze how economic growth is being impacted by remittance in five selected South Asian countries between the period 1975 and 2017. Estimated results from panel-data estimation techniques exhibit a positive relation between economic growth and remittance in these countries. The results from Granger-causality tests suggest that remittance plays a catalyst role to bring economic growth but economic growth doesn't play any role to bring remittance while Dumitrescu Hurlin Causality tests found a bi-directional relationship. Important finding of the study is that remittance boost economic growth in South Asian region.
\end{abstract}

Keywords: causality, economic growth, panel data, remittance, South Asia

\section{Introduction}

Remittance is the rising external root of funds for developing countries (Straubhaar \& Vâdean, 2006) . It creates significant effect on economic growth. Remittance contributes to economic growth via several channels. The first channel is through investment in local markets of the home country. The remitted money can contribute to the capital formation and thus can promote economic growth (Goschin, 2014). The second channel is the consumption of remitted money in the home country. Even if the remitted money is not invested in the home country, the remittance has a crucial multiplier effect through consumption (Goschin, 2014). The money spent in local markets on consumption can raise the sales and thus can raise production and employment in the home country (Lowell \& De La Garza, 2000). Remittance also plays a role in increasing entrepreneurship. It helps the rural people who do not have facilities for credit to launch micro-enterprises (Kaijage \& Siegel, 2008).

The continuous flux in the remittance streams in developing countries and their subsequent pecuniary effects fascinated huge interest from the intellectuals globally (Goschin, 2014). There are two prime theoretic opinions about remittances such as the family approach and the portfolio approach (Goschin, 2014). First one embroiling that humanitarian motives decide to send money by the immigrant to patronage the family depended on him and second one state that remittance works as an excellent investment hatched by the immigrant in its home country (Goschin, 2014). Remittances, in both cases, would prompt in receiving country's economic growth either by increasing production or consumption.

Moreover, there is a positive impact on creating human capital of remittance. The remitted money help increasing the number of school enrollment and human capital in the home country because the country spends school fees and health related factors of migrant's household (Edwards \& Ureta, 2003).

It is regarded that South Asia has become most active remittance markets around the world. Over the last few decades, migratory outflow and remittance flow has increased in South Asian countries. Due to the rapid grown economic activity of Gulf region and surplus of labor, many countries in this region have long tradition of migration (Straubhaar \& Vâdean, 2006).

The South Asian countries receive nearly one-fourth of total global remittance (Rahman, Yong, \& Ullah, 2014). Following World Bank's latest brief, (Note 1) remittances reached a peaked in 2018 in low and middle income countries. The Bank counts the flow of remittances towards low and middle income countries that reached record 
$\$ 529$ billion in 2018 compared to $\$ 483$ billion in 2017 that contributed to increase about $9.6 \%$ over the previous record. Global remittance flows also became $\$ 689$ billion in 2018 compared to $\$ 633$ billion in 2017. Remittance inflows increased almost 7\% in East Asia and 12\% in South Asia that were driven by a robust US economy and outward flows of remittance growth from some GCC (Note 2) countries along with Russian federation. Regionally excluding China, remittances were crucially stronger than foreign direct investment flows in 2018( $\$ 344$ billion) than low and middle income countries ( $\$ 462$ billion). Remittances increased more than $14 \%$ in India and this contributed flood disaster Kerala by boosting financial condition of the families. Pakistan remittance growth was little bit moderate (7\%) due to significant reductions of inflows of remittance from Saudi Arabia. In Bangladesh there was a robust increment of remittance in 2018 (15\%) (World Bank). Figure 1 shows the trends of remittance inflows to South Asian region (World Bank).

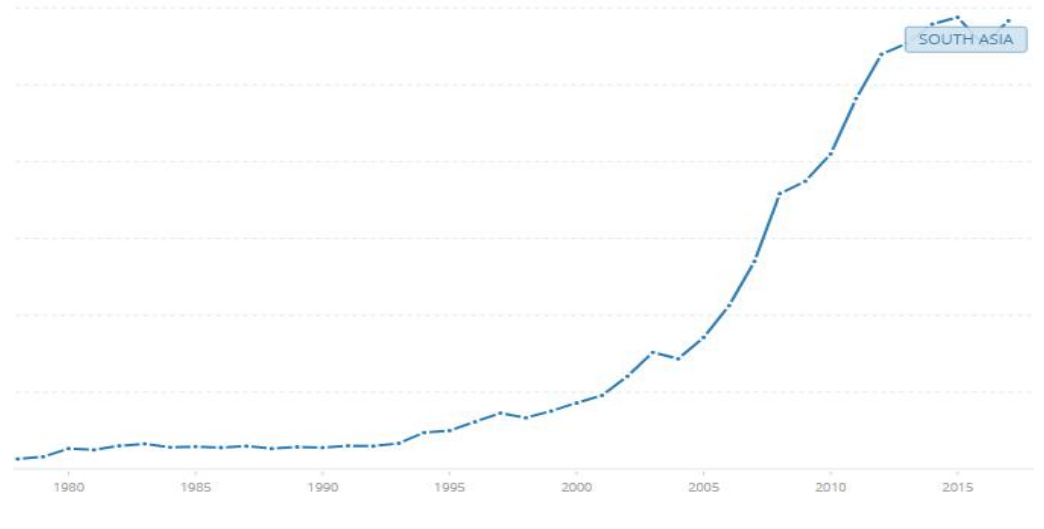

Figure 1

Source: Word Bank data base.

The table shows the volume of remittance for 5 major South Asian regions. The top remittance recipient country is India, followed by Pakistan and Bangladesh.

Table 1. Volume of remittance inflows to South Asia in 2017

\begin{tabular}{ll}
\hline Country & Remittance (in thousand) \\
\hline Bangladesh & $13,498,232.55$ \\
\hline India & $68,967,175.50$ \\
\hline Nepal & $6,928,134.01$ \\
\hline Sri Lanka & $7,190,296.02$ \\
\hline Pakistan & $19,689,000.00$ \\
\hline
\end{tabular}

Source: World Bank

The present study attempts to examine the result of remittance inflows to major South Asian economies. The paper has been organized as follows: the previous study on remittance and its relationship with economic growth, the methodology, the results analysis and discussion, and finally the conclusion.

\section{Literature Review}

The literature based on remittance and economic growth shows mixed results ranging from positive to negative and sometimes no relation. Mamun, Sohag, Uddin, \& Shahbaz (2015) found that remittance promotes domestic output for the nations with larger remittance inflows and larger workforce but the effect of remittance decreases after a certain level. Imai, Gaiha, Ali, \& Kaicker (2014) investigated whether remittance has any impact on economic growth based on 24 Asia and Pacific countries. The panel estimation results show two findings; economic growth 
positively affects to remittance and the volatility of remittance negatively affects economic growth. Meyer \& Shera(2016) explored this relationship on 6 high remittance recipient countries and panel data for the countries has been used spanning from 1999-2013, suggest that a positive relationship exists in economic growth and remittance and conclude that the effect increases due to higher GDP. Marwan et al.(2013) worked on export, foreign aid, remittance, and economic growth and found a long run positive relation among those variables. Jayaraman, Choong, Tunku, Rahman, \& Kumar(2012) also found positive relations on remittance and economic growth based on the data 1970 to 2009 . Tchantchane, Rodrigues, \& Fortes(2013) also presented positive coordination between those variables in the case of Philippines using ARDL model.

Jahjah, Chami, \& Fullenkamp(2003) argue that remittance is not benefit-driven and there exists an inverse relationship between remittance and GDP growth. Lim \& Simmons (2015) examined this relationship on "Caribbean Community and Common Market (CARICOM)" using panel co-integration test, the results suggest no long-run relations between those variables and thus the region did not use their remittance for productive activities. Gapen, Chami, Montiel, Barajas, \& Fullenkamp, (2009) find no relation between remittance and economic growth.

Pradhan, Upadhyay, \& Upadhyaya (2008) found small positive outcome of remittance on economic growth and a linear regression model has been applied with the data of 36 countries in this regard. Faini (2001) showed same relation between economic growth and remittances. From another perspective, Spatafora \& Aggarwal, (2005) presented a negative relationship between per capita output growth and remittances. Gapen et al., (2009) found inverse relationship between those variable with a sample of 113 countries.

Qayyum, Javid, \& Arif, (2018) studied the relation between remittances and its outcomes on economic growth and poverty alleviation saying that remittance promotes social-economic growth. Ahortor \& Adenutsi, (2008) found significantly positive effect of remittance on economic growth. Fayissa \& Nsiah, (2010) examined this relationship with the panel data for the period of 1980 to 2005 utilizing the neo-classical growth model. The results showed that remittance is more beneficial than official development assistant (ODA) and foreign direct investment in promoting economic growth. Yaseen, (2012) and Datta \& Sarkar, (2014) found positive impact between remittance and economic growth. But Datta \& Sarkar, (2014) also explained if remittance is spent on unproductive ways then it has an opposite effect on economic growth. But if it is spent on children's educational and health expenses, it promotes economic growth.

\section{Methodology}

\subsection{Model Specification}

Panel data include $\mathrm{N}^{*} \mathrm{~T}$ observations for the model that provide robust results and conserve more information for the model than pure time series and pure cross-sectional data. This analysis includes 5 south Asian countries namely Nepal, India, Sri Lanka, Pakistan and Bangladesh for the year 1975-2017 (total 215 observations). Data are collected from World Development Indicators (WDI) which is an authentic data source over the world. Aim of the study is to check the remittance and economic growth relation of the mentioned countries. As a proxy of economic growth Per capita GDP of these countries has been used. For the model specification variable $\mathrm{Y}$ is used to designate per capita real GDP and variable $\mathrm{X}$ is used for remittances.

The initial model is defined as follows:

$$
(\mathrm{LY})_{\mathrm{it}}=\mathcal{B} 0+\mathcal{B} 1(\mathrm{LX})_{\mathrm{it}}+\varepsilon_{\mathrm{it}}
$$

Where,

LY $=$ Natural log of real GDP per capita

LX= Natural log of Personal remittances (Note 3) received.

$\mathcal{B}_{0}=$ Intercept term

$\mathcal{B}_{1}=$ Slope coefficient of the independent variable remittance.

$\varepsilon=$ Error term

Variables' data are transformed into the logarithm and three different models (Note 4) are applied to estimate the coefficients.

\subsection{Panel Estimation Techniques}

\subsubsection{The Pooled Regression Method}

In the pooled model, data from different individuals are combined with different time series. If ordinary least square 
(OLS) is applied in a pooled model the estimation is called Pooled Least Square Estimation (Asteriou \& Hall, 2015). The model is used when there is homogeneity across cross-sections.

By observing the data of the model, the pooled regression method estimates a constant intercept and the slope of the model regardless of the time period and cross-sectional unit. That is, it assumed the same intercept and slope for all the countries and years.

In the study the pooled model is:

$$
(\mathrm{LY})_{\mathrm{it}}=\mathcal{B}_{0}+\mathcal{B}_{1}(\mathrm{LX})_{\mathrm{it}}+\varepsilon_{\mathrm{it}}
$$

The variables have been transformed into a natural logarithm. L stands for logarithm.Y stands for economic growth which is a proxy of GDP per capita and X stands for personal remittance received. The "it" denotes the $\mathrm{i}^{\text {th }}$ countries for the $\mathrm{t}^{\text {th }}$ period. $\mathcal{B}_{0}$ and $\mathcal{B}_{1}$ are intercept and slope coefficient, respectively. However, the intercept and slope coefficient is constant for all the countries and thus overlook individual heterogeneity. The parameters are unbiased and consistent.

\subsubsection{The Fixed Effects Method (FE)}

The individuals of the fixed effect of the panel estimation don't change over time. But the individuals may or may not be correlated with the individual dependent variables. In a repeated test, the levels are the same for the fixed effects of the variables and these effect uses $\mathrm{df}$ (degrees of freedom) for every level (minus one). So there is a loss of $\mathrm{df}$ in fixed effect. The fixed effects model for the study is-

$$
(\mathrm{LY})_{\mathrm{it}}=\mathcal{B}_{0 \mathrm{i}}+\mathcal{B}_{1}(\mathrm{LX})_{\mathrm{it}}+\varepsilon_{\mathrm{it}}
$$

The constant slope-coefficient remains same for all the individuals and time. But the intercept term $\beta_{0 \mathrm{i}}$ is different for different countries not for the different time periods of the individuals. And the individual heterogeneity [each country's specific character regardless of time] is captured by individual intercept term which is also known as the fixed effect model. Only the intercept term in fixed effect is assumed to be different in the model (Hill, Griffiths, \& Lim, 2018).

\subsubsection{The Random Effects Method (RE)}

In this type of model, it is assumed that the samples are drawn randomly and can influence the population and the intercept is random as well. For unbalanced data Random effect is important. The individuals of the random effect differ across the time and the regressed are running toward the mean. One df [degrees of freedom] is used in the random effect as it estimates the effect in terms of variance. And the standard errors are large in this effect.

The random effect model for the estimation of our study is:

Where, $\mathcal{B}_{0 i}=\overline{\mathcal{B}}_{0}+u_{i}$

$$
(\mathrm{LY})_{\mathrm{it}}=\mathcal{B}_{0 \mathrm{i}}+\mathcal{B}_{1}(\mathrm{LX})_{\mathrm{it}}+\varepsilon_{\mathrm{it}}
$$

Or, $(\mathrm{LY})_{\mathrm{it}}=\left(\overline{\mathcal{B}}_{\mathrm{o}}+\mathrm{u}_{\mathrm{i}}\right)+\mathcal{B}_{1}(\mathrm{LX})_{\mathrm{it}}+\varepsilon_{\mathrm{it}}$

And $\mathcal{B}_{0}$ denotes the fixed part of the $\mathcal{B}_{0 \mathrm{i}}$ that refers population average while the $\mathrm{u}_{\mathrm{i}}$ denotes the difference part of $\mathcal{B}_{0 \mathrm{i}}$ that refers to the difference of random individual from population average. The random error term $\left(u_{i}\right)$ is known as the Random effect that shows the difference between random individuals from the mean. The error term in random effect is assumed to differ in the model.

Here error term $\varepsilon_{i, t}$ follows the subsequent assumptions:

a) The mean of the error term is zero.

b) The variance of error terms is constant, i.e. homoscedasticity (Error terms are uncorrelated).

\subsection{The Redundant Fixed Effects Tests}

To check the presence of heterogeneity within a model the Redundant Fixed Effects test is used. To investigate whether there is heterogeneity in the model "redundant fixed effect" test can be used. The null and alternative hypotheses are as follow:

$\mathrm{H}_{0}: \mathcal{B}_{01}=\mathcal{B}_{02}=\mathcal{B}_{03}=\mathcal{B}_{04}=\ldots \ldots \ldots \ldots=\mathcal{B}_{0 \mathrm{~N}}=\mathcal{B}_{0}$ (No heterogeneity)

$\mathrm{H}_{1}: \mathcal{B}_{01} \neq \mathcal{B}_{02} \neq \mathcal{B}_{03} \neq \mathcal{B}_{04} \neq \ldots \ldots \ldots \ldots \ldots \neq \mathcal{B}_{0 \mathrm{~N}} \neq \mathcal{B}_{0}$ (Heterogeneity is present)

If the p-value associated with Cross-section Chi-square, is less than $5 \%$ level of significance, the null hypothesis is rejected. And if the null hypothesis can be rejected when heterogeneity is present in the model and pooled regression 
model should not be used, the model should use whether fixed effect or random effect technique.

\subsection{The Hausman Test}

Hausman test is used to check the right model from the RE and FE. This test checks the correlation of regressors and error term in random effect model. If the Hausman test results suggest that there is no correlation between error components and the regressors then both random and fixed effect models are approximately equal and they are consistent. Thus either one of both estimators can be used if the Hausman test shows no correlation between the error components and regressors. However, if there exists a correlation of error component with any of regressors, random effect estimation technique shows inconsistent results. In this situation, the technique of using random effect model should not be applicable rather the fixed effect model is applicable.

\subsection{Panel Causality Tests}

The host country's GDP can affect the remittance inflows (Barua, 2009). For instance, economic growth leads to skilled labor through education. And the skilled labor force, if migrate, can send more remittances than unskilled labor (Islam \& Nasrin, 2015). Identifying the direction of causality is important for policy intervention for economic growth and remittance. To check the causality direction of remittances and growth, we first applied standard panel Granger causality. The panel Granger causality for regression takes the following form:

$$
\begin{aligned}
& Y_{i, t}=\gamma_{0, i}+\gamma_{1, i} Y_{i, t-1}+\cdots \cdots+\gamma_{1, i} Y_{i, t-1}+\delta_{1, i} X_{i, t-1}+\cdots \cdots+\delta_{1, i} X_{i, t-1}+\tau_{i, 1} \\
& X_{i, t}=\gamma_{0, i}+\gamma_{1, i} X_{i, t-1}+\cdots \cdots+\gamma_{1, i} X_{i, t-1}+\delta_{1, i} Y_{i, t-1}+\cdots \cdots+\delta_{1, i} Y_{i, t-1}+\tau_{i, 1}
\end{aligned}
$$

The coefficient in standard panel Granger causality is assumed to be same across the cross-section. An opposite assumption, coefficients are not same across cross section, was adopted another panel Granger causality test suggested by Dumitrescu \& Hurlin, (2012) that has three advantages. First, the cross-sectional dependency problem of panel can be been taken into consideration. Second, this test can equally be applied whether $\mathrm{N}>\mathrm{T}$ or $\mathrm{N}<\mathrm{T}$. Third, this test can be used for unbalanced panel data. However, Monte Carlo experiments suits well in case of a short span of data.

The model specification of this test is as follows:

$$
\mathrm{Y}_{\mathrm{i}, \mathrm{t}}=\alpha_{\mathrm{i}}+\sum_{i=1}^{k} \gamma i^{(k)} \mathrm{Y}_{\mathrm{i}, \mathrm{t}-\mathrm{k}}+\sum_{i=1}^{k} \beta i^{(k)} \mathrm{X}_{\mathrm{i}, \mathrm{-t}}+\varepsilon_{i, t}
$$

Here the null and alternative hypothesis is defined as:

$\mathrm{H}_{0}: \beta_{\mathrm{i}}=0 ;(\mathrm{i}=1 \ldots . \mathrm{N})$ (absence of homogenous Granger causality)

$\mathrm{H}_{0}: \beta_{\mathrm{i}}=0 ;\left(\mathrm{i}=1 \ldots \ldots \mathrm{N}_{1}\right) ; \beta_{\mathrm{i}} \neq 0,\left(\mathrm{i}=\mathrm{N}_{1}+1, \mathrm{~N}_{1}+2, \ldots . \mathrm{N}\right)$ (existing of Granger causality in at least one cross-section).

\section{Results and Discussion}

The results from regression analysis have been presented in table, 2, 3, and 4. Table 2 presents the results of Pooled least square estimation. The dependent variable is GDP per capita and the independent variable is remittance inflow. The value coefficient is 0.128 which is positive. This implies that, if remittance increases $1 \%$, it will increase GDP per capita by $0.128 \%$. The associated P-value is below the $5 \%$ level of significance; therefore, the coefficient is significant. As a result, a significant positive impact of remittance on GDP per capita has been observed.

Table 3 presents the results of the fixed effect model estimation. The table shows that the coefficient is 0.2268 which is positive and the associated P-value is below the 5\% level of significance. This implies that, if remittance increases $1 \%$, it will increase GDP per capita by $0.2268 \%$. The random effect model results presented in table 4 show almost the same results. Thus in our analysis, the three type of regression model show a significant remittance' impact on economic growth following in South Asian countries.

The redundant fixed effect test and Hausman test results are presented in Table 5 and Table 6 respectively. The results of redundant fixed effect test reject the null hypothesis. This indicates that there is heterogeneity in the model and therefore, in this case, the Pooled regression will not provide reliable results. The Hausman test results suggest that the null hypothesis has no correlation between error components and regressors, as a result it could not be rejected which also clearly indicates the presence of correlation. This implies that the random effect is not inconsistent and either of fixed effect and random effect can be used.

The results of the causality test are presented in Table 7 and 8 . The panel causality test results of Dumitrescu Hurlin are shown in Table 7 where Lag 1 and lag 2 both have been checked. The P-values associated with test-statistics in 
both cases are less than the significance level. The null hypothesis of no causality from remittance to economic growth has been rejected. And again, the null hypothesis of no causality from economic growth to remittance has also been rejected which indicates that there exists a bi-directional causality between remittance and economic growth. Table 8 presents the results of Granger causality. The results show that in case of lag 1 and lag 2, the null hypothesis of no causality from remittance to economic growth has been rejected but the null hypothesis of no causality from economic growth to remittance has not been rejected. This result suggests that unidirectional causality is running from remittance to economic growth but not from economic growth to remittance.

Table 2. Estimated coefficient

Table 2A. Panel least squares estimation

\begin{tabular}{|c|c|c|c|c|}
\hline Variable & Coefficient & Std. Error & t-Statistic & Prob. \\
\hline LREMM & 0.128280 & 0.021308 & 6.020397 & 0.0000 \\
\hline $\mathrm{C}$ & 3.913366 & 0.457952 & 8.545356 & 0.0000 \\
\hline R-squared & & & Mean dependent var & 6.660987 \\
\hline Adjusted R-squared & & & S.D. dependent var & 0.574593 \\
\hline S.E. of regression & & & Akaike info criterion & 1.572958 \\
\hline Sum squared resid & & & Schwarz criterion & 1.606527 \\
\hline Log likelihood & & & Hannan-Quinn criter. & 1.586550 \\
\hline F-statistic & & & Durbin-Watson stat & 0.006340 \\
\hline Prob(F-statistic) & & & & \\
\hline
\end{tabular}

Table 2B. The fixed effects model

\begin{tabular}{|c|c|c|c|c|}
\hline Variable & Coefficient & Std. Error & t-Statistic & Prob. \\
\hline LREMM & 0.226819 & 0.008930 & 25.40022 & 0.0000 \\
\hline $\mathrm{C}$ & 1.802777 & 0.191744 & 9.401989 & 0.0000 \\
\hline R-squared & 0.894722 & & Mean dependent var & 6.660987 \\
\hline Adjusted R-squared & 0.891937 & & S.D. dependent var & 0.574593 \\
\hline S.E. of regression & 0.188886 & & Akaike info criterion & -0.465063 \\
\hline Sum squared resid & 6.743109 & & Schwarz criterion & -0.364355 \\
\hline Log likelihood & 51.34364 & & Hannan-Quinn criter. & -0.424288 \\
\hline F-statistic & 321.2486 & & Durbin-Watson stat & 0.104717 \\
\hline Prob(F-statistic) & 0.000000 & & & \\
\hline \multicolumn{5}{|c|}{ Table $2 \mathrm{C}$. The random effects model } \\
\hline Variable & Coefficient & Std. Error & t-Statistic & Prob. \\
\hline LREMM & 0.226428 & 0.008924 & 25.37240 & 0.0000 \\
\hline $\mathrm{C}$ & 1.794137 & 0.301330 & 5.954064 & 0.0000 \\
\hline \multicolumn{5}{|l|}{ Effects Specification } \\
\hline & & & S.D. & Rho \\
\hline Cross-section random & & & 0.521344 & 0.8840 \\
\hline Idiosyncratic random & & & 0.188886 & 0.1160 \\
\hline R-squared & 0.768807 & & Mean dependent var & 0.382981 \\
\hline Adjusted R-squared & 0.767609 & & S.D. dependent var & 0.393090 \\
\hline S.E. of regression & 0.189174 & & Sum squared resid & 6.906819 \\
\hline F-statistic & 641.8013 & & Durbin-Watson stat & 0.101945 \\
\hline
\end{tabular}


Table 3. Hypothesis testing

\begin{tabular}{llll}
\hline \multicolumn{2}{l}{ Table 3A. The redundant fixed effects tests } & \\
\hline Effects Test & Statistic & d.f. & Prob. \\
\hline Cross-section F & 330.600828 & $(4,189)$ & 0.0000 \\
\hline Cross-section Chi-square & 405.414132 & 4 & 0.0000 \\
\hline Table 3B. The hausman test & & & \\
\hline Test Summary & Chi-Sq. Statistic & Chi-Sq. d.f. & Prob. \\
\hline Cross-section random & 1.522834 & 1 & 0.2172 \\
\hline
\end{tabular}

Table 4. Panel causality tests

\begin{tabular}{lccc}
\hline \multicolumn{2}{l}{ Table 4A. Pairwise Dumitrescu Hurlin panel causality tests (Lags-1) } & & \\
\hline Null Hypothesis & W-Stat. & Zbar-Stat. & Prob. \\
\hline LREMM does not homogeneously cause LGDPC & 2.73241 & 2.35358 & 0.0186 \\
\hline LGDPC does not homogeneously cause LREMM & 9.25596 & 11.5611 & 0.0000 \\
\hline Table 4A. Pairwise Dumitrescu Hurlin panel causality tests (Lags-2) & & Prob. \\
\hline \multicolumn{2}{l}{ W-Stat. } & Zbar-Stat. & 0.0298 \\
\hline LGDPC does not homogeneously cause LREMM & 5.39335 & 2.17267 & 0.0002 \\
\hline
\end{tabular}

Table 5. Granger causality tests

\begin{tabular}{|c|c|c|c|}
\hline \multicolumn{4}{|l|}{ Null Hypothesis } \\
\hline LREMM does not homogeneously cause LGDPC & 190 & 12.4091 & 0.0005 \\
\hline LGDPC does not homogeneously cause LREMM & & 0.19195 & 0.6618 \\
\hline \multicolumn{4}{|l|}{ Table 5B. Pairwise Granger causality tests (Lags-2) } \\
\hline & Obs. & F-Statistic & Prob. \\
\hline LREMM does not homogeneously cause LGDPC & 185 & 6.65473 & 0.0016 \\
\hline LGDPC does not homogeneously cause LREMM & & 0.71599 & 0.4901 \\
\hline
\end{tabular}

\section{Conclusion and Policy Recommendation}

In this study various panel estimation techniques have been used i.e. Pooled Least Square, Fixed and Random effect model for finding out the impact of remittance on economic growth. For choosing an appropriate model, the Redundant fixed effect test and Husman test have been used in this study. The results show that both fixed effect and random effect models are appropriate to run the analysis. To check the causality direction of panel Granger Causality and Dumitrescu Hurlin tests have been used. The outcomes of Granger causality indicate unidirectional causality from economic growth to remittance. That is, remittance agencies economic growth but economic growth does not agencies remittance. On the contrary, the outcomes from Dumitrescu Hurlin Causality tests indicate bi-directional causality between remittance and economic growth and In other words, both economic growth and remittance accelerate each other.

The volume of remittance inflows to South Asian countries has risen sharply in recent decades. The literature of the remittance-economic growth relationship' suggests that the remittance has either positive, negative or no impact on economic growth. This study finds that remittance has significant positive effect on economic growth which might be because of consumption multiplier. Since South Asia is characterized by large population size. Or the possible 
reason might be that the remitted money is being spent on investment, plausibly, small scale investment. The present study findings are consistent with those of Cooray, (2012). From the findings it is recommended that governments in South Asia and relevant agencies should consider the remittance inflows as a contributor to the economic growth and should ease the direction of sending remittance so that the migrants can send more money to contribute to economic growth.

\section{References}

Ahortor, C. R. K., \& Adenutsi, D. E. (2008). The impact of remittances on economic growth in small-open developing economies. https://doi.org/10.3923/jas.2009.3275.3286

Al Mamun, M.., Sohag, K., Uddin, G. S., \& Shahbaz, M. (2015). Remittance and domestic labor productivity: Evidence from remittance recipient countries. Economic Modelling. https://doi.org/10.1016/j.econmod.2015.02.024

Asteriou, D., \& Hall, S. G. (2015). Applied econometrics (3rd ed., p. 345). Macmillan International Higher Education.

Barua, S. (2009). Determinants of Workers' Remittances in Bangladesh: An Empirical Study. SSRN. https://doi.org/10.2139/ssrn.1398690

Cooray, A. (2012). The impact of migrant remittances on economic growth: evidence from South Asia. Review of International Economics, 20(5), 985-998. https://doi.org/10.1111/roie.12008

Datta, K., \& Sarkar, B. (2014). Relationship between Remittances and Economic Growth in Bangladesh: An Econometric Study. https://doi.org/10.2139/ssrn.2375991

Dumitrescu, E.-I., \& Hurlin, C. (2012). Testing for Granger non-causality in heterogeneous panels. Economic Modelling, 29(4), 1450-1460. https://doi.org/10.1016/j.econmod.2012.02.014

Edwards, A. C., \& Ureta, M. (2003). International migration, remittances, and schooling: evidence from El Salvador. Journal of Development Economics, 72(2), 429-461. https://doi.org/10.1016/S0304-3878(03)00115-9

Fagerheim, M. G. (2015). Impact of remittances on economic growth in ASEAN: An empirical analysis, 1980-2012.

Faini, R. (2001). Development, Trade, and Migration. Washington, DC: IMF

Fayissa, B., \& Nsiah, C. (2010). The Impact of Remittances on Economic Growth and Development in Africa. The American Economist. https://doi.org/10.1177/056943451005500210

Gapen, M. T., Chami, R., Montiel, P., Barajas, A., \& Fullenkamp, C. (2009). Do Workers' Remittances Promote Economic Growth?. IMF Working Papers. https://doi.org/10.5089/9781451873009.001

Goschin, Z. (2014). Remittances as an economic development factor. Empirical evidence from the CEE countries. Procedia Economics and Finance, 10, 54-60. https://doi.org/10.1016/S2212-5671(14)00277-9

Hill, R. C., Griffiths, W. E., \& Lim, G. C. (2018). Principles of econometrics (4th ed., pp. 543-544). John Wiley \& Sons.

Imai, K. S., Gaiha, R., Ali, A., \& Kaicker, N. (2014). Remittances, growth and poverty: NEW evidence from Asian countries. Journal of Policy Modeling. https://doi.org/10.1016/j.jpolmod.2014.01.009

Islam, M. S., \& Nasrin, S. (2015). Driving forces of remittance inflow in Bangladesh: An empirical study. International Journal of Economics and Finance, 7(6), 126. https://doi.org/10.5539/ijef.v7n6p126

Jahjah, S., Chami, R., \& Fullenkamp, C. (2003). Are Immigrant Remittance Flows a Source of Capital for Development. IMF Working Papers. https://doi.org/10.5089/9781451859638.001

Jayaraman, T. K., Choong, C.-K., Tunku, U., Rahman, A., \& Kumar, R. R. (2012). Role of remittances in India's economic growth. Global Business and Economics Review. https://doi.org/10.1504/GBER.2012.047802

Kaijage, J. N., \& Siegel, M. (2008). The impacts of international remittances on receiving countries at the micro and macro level and policy options for increasing remittance effectiveness: Reviewing the literature. Unpublished MS Thesis, Maastricht Graduate School of Governance, Maastricht University, Maastricht, Netherlands.

Lim, S., \& Simmons, W. O. (2015). Do remittances promote economic growth in the Caribbean Community and Common Market?. Journal of Economics and Business. https://doi.org/10.1016/j.jeconbus.2014.09.001

Lowell, B. L., \& De La Garza, R. O. (2000). The developmental role of remittances in US Latino communities and in Latin American countries. Final Project Report Prepared for the Thomás Rivera Policy Institute (TRPI), 
University of Texas, Austin, Texas, and the Inter-American Dialogue.

Marwan, N. F., Kadir, N. A. A., Hussin, A., Zaini, A. A., Ab. Rashid, M. E., \& Helmi, Z. A. G. (2013). Export, Aid, Remittance and Growth: Evidence from Sudan. Procedia Economics and Finance. https://doi.org/10.1016/S2212-5671(13)00211-6

Meyer, D., \& Shera, A. (2016). The impact of remittances on economic growth: An econometric model. Economia. https://doi.org/10.1016/j.econ.2016.06.001

Pradhan, G., Upadhyay, M., \& Upadhyaya, K. (2008). Remittances and economic growth in developing countries. The European Journal of Development Research, 20(3), 497-506. https://doi.org/10.1080/09578810802246285

Qayyum, B., Javid, M., \& Arif, U. (2018). The Impact of Remittances on Economic Growth and Poverty Reduction. Munich Personal RePEc Archive. https://doi.org/10.1177/056943451005500210

Rahman, M. M., Yong, T. T., \& Ullah, A. K. M. A. (2014). Migrant Remittances in South Asia: An Introduction. In Migrant remittances in South Asia (pp. 1-30). Springer. https://doi.org/10.1057/9781137350800_1

Spatafora, N., \& Aggarwal, R. (2005). Two current issues facing developing countries. World Economic Outlook, 69-107.

Straubhaar, T., \& Vâdean, F. P. (2006). International migrant remittances and their role in development. https://doi.org/10.1787/9789264013896-3-en

Tchantchane, A., Rodrigues, G., \& Fortes, P. C. (2013). An empirical study on the importance of remittance and educational expenditure on growth: Case of the Philippines. Applied Econometrics and International Development. https://doi.org/10.1097/MOP.0b013e328344c393

Yaseen, H. S. (2012). The positive and negative impact of remittances on economic growth in MENA countries.

\section{Notes}

Note 1. Migration and Development Brief available at https://www.worldbank.org/en/news/pressrelease/2019/04/08/record-high-remittances-sent-globally-in-2018

Note 2. Gulf Cooperation Council

Note 3. Personal remittances include a) personal transfer and b) employee's compensation. Personal transfer includes all present transfers in cash money received by the resident and non-resident households. Compensation of employees includes short term workers' incomes who are employed outside of their home economy.

Note 4. Three model are estimated by three method named; Pooled Regression Method, Fixed Effects Method, and Random Effects Method. 